\title{
Indolebutyric acid in "pulse" treatment on the rooting of Luehea divaricata minicuttings
}

\author{
Karol Buuron da Silva ${ }^{1}$ (i) Lia Rejane Silveira Reiniger ${ }^{*}$ (i) Silvia Machado dos Santos Rabaiolli ${ }^{1}$ \\ Charlene Moro Stefanel ${ }^{1}$ (D) Leandro Dutra da Silva ${ }^{2}$ (D)
}

${ }^{1}$ Programa de Pós-graduação em Engenharia Florestal, Universidade Federal de Santa Maria (UFSM), 97105-900, Santa Maria, RS, Brasil. E-mail: liarsr@ufsm.br. "Corresponding author.

${ }^{2}$ Curso de Engenharia Florestal, Universidade Federal de Santa Maria (UFSM), Santa Maria, RS, Brasil.

ABSTRACT: The objective of the present research was to evaluate the effect of different concentrations of indolebutyric acid (IBA) on the rooting of Luehea divaricata minicuttings under two different cultivation periods in a greenhouse environment. The minicuttings were immersed in a hydroethanolic solution containing IBA. All minicuttings survived after 30 and 60 days of cultivation. Root formation at 30 days of cultivation with $1000 \mathrm{mg} \mathrm{L}^{-1}$ of IBA was $91.7 \%$, the same rate as that observed with $4000 \mathrm{mg} \mathrm{L}^{-1}$. At the $1000 \mathrm{mg} \mathrm{L} \mathrm{L}^{-1} \mathrm{concentration}$, the number of roots was the greatest among all treatments, with 8.42 roots per minicutting after 30 days of cultivation. After 30 days of cultivation, the formation and number of roots with the use of $1000 \mathrm{mg} \mathrm{L} \mathrm{L}^{-1}$ of IBA in the "pulse" treatment produced the best outcome results, allowing the plants to spend less time in a greenhouse at a reduced concentration of auxin when compared with other treatments. However, to obtain higher averages of secondary root formation, root length, and number of leaves, it is necessary to increase the cultivation period to 60 days. Key words: minicutting technique, IBA, auxin, vegetative propagation.

\section{Ácido indolbutírico em tratamento "pulse" sobre o enraizamento de miniestacas} de Luehea divaricata

RESUMO: O objetivo do presente trabalho foi avaliar o efeito de diferentes concentrações do ácido indolbutírico (AIB) em dois períodos de cultivo em casa de vegetação sobre o enraizamento de miniestacas de Luehea divaricata. As miniestacas foram imersas por 10 s em solução hidroetanólica contendo AIB. Todas as miniestacas sobreviveram tanto após 30 como 60 dias de cultivo. A formação de raízes aos 30 dias com

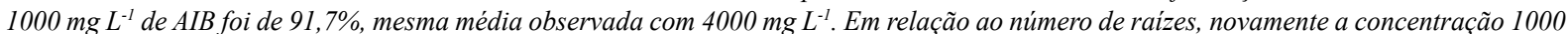
$m g L^{-1}$ destacou-se em relação às demais concentrações, e já aos 30 dias de cultivo houve 8,42 raizes por miniestaca. Aos 30 dias de cultivo, a formação e o número de raízes na presença de $1000 \mathrm{mg} L^{-1}$ de AIB em tratamento "pulse" já produz resultados satisfatórios, permitindo que as plantas permaneçam menor tempo em casa de vegetação utilizando-se uma concentração reduzida de auxina, comparativamente àquelas que foram testadas. No entanto, para obter maiores médias de formação de raízes secundárias, comprimento das raizes e número de folhas é necessário prolongar o cultivo pelo periodo de 60 dias.

Palavras-chave: miniestaquia, AIB, auxina, propagação vegetativa.

\section{INTRODUCTION}

The Atlantic Forest is one of the most biodiverse biomes in the world, with about 20,000 plant species, of which 8,000 are endemic. It is considered the richest biome in the world in tree diversity, with 454 distinct species in a single hectare. In addition, the forest regulates the flow of freshwater, ensures soil fertility, controls the climate, and preserves invaluable natural and cultural heritage. However, because approximately $70 \%$ of the Brazilian population lives in this region, it is one of the biomes that has suffered the most from environmental impacts of the country's economic cycles. Today this biome has been reduced to about
7\% of its original area (BRASIL, 2015; CAMPANILI; SCHAFFER, 2010).

One native forest species of this rich and biodiverse biome is the Luehea divaricata Mart. \& Zucc., more commonly known as the "açoita-cavalo," a member of the Malvaceae family. The natural population of Luehea divaricata and many other native species have drastically decreased owing to the intense exploitation of the Atlantic Forest, making it increasingly difficult to search for specimens suitable for commercial and ecological use (LORENZI, 2008). In view of this, many difficulties are encountered in obtaining viable seeds with good sanitary and phenotypic characteristics, hindering the seminal propagation and perpetuation of species. Another 
issue that hinders the propagation of the Luehea divaricata is the germination rate of collected seeds. In a germination test performed on blotting paper, the germination rate of a seed lot collected in 2010 and stored for 7 months was only $27 \%$ (DUTRA et al., 2016), which confirmed results of previous studies that reported that the seed germination of Luehea divaricata is very variable, ranging between $20 \%$ and $75 \%$ (LORENZI, 2008). Thus, the minicutting technique may be away to overcome difficulties in propagating native species, especially species with seeds that are difficult to obtain and germinate, such as Luehea divaricata.

Minicutting consists of using plant sprouts propagated by cuttings or seeds. This method requires a smaller area to make a clonal mini garden, which facilitates ease of management in terms of irrigation, and pest and disease control, there by producing minicuttings of higher quality more quickly, with a higher rooting percentage (XAVIER et al.; 2003). One of the most common ways to induce adequate rooting in the minicuttings is via the exogenous application of growth regulators in the base, increasing the auxin content in the tissue. The most used auxin for inducing rooting in minicuttings is indolebutyric acid (IBA), because it is a photostable substance with a localized reaction, and is less sensitive to biological degradation when compared to other types of auxins. The use of appropriate IBA concentrations is of utmost importance in minicutting, and the optimal dose varies with the species (ASSIS; TEIXEIRA, 1998).

For these reasons, the objective of the present research was to compare the effect of different concentrations of IBA and the cultivation period on the rooting of seminal minicuttings of Luehea divaricata.

\section{MATERIALS AND METHODS}

The test was conducted at the Tissue Culture Laboratory of the Biotechnology and Breeding Center, Department of Crop Production, and at the Silviculture and Forest Nursery Laboratory, Department of Forest Sciences, both located at the Federal University of Santa Maria - UFSM, in Santa Maria, Rio Grande do Sul, Brazil.

The experimental design was set in a completely randomized $4 \times 2$ factorial array, in which the first factor consisted of different concentrations of IBA $\left(0,1000,2000\right.$, or $\left.4000 \mathrm{mg} \mathrm{L}^{-1}\right)$ while the second factor consisted of two periods of cultivation (30 or
60 days), totaling 8 treatments with 12 repetitions, each one using a minicutting of Luehea divaricata. The minicuttings prepared were approximately 7 to $10 \mathrm{~cm}$ in length, containing a pair of leaves cut in half, using the stem of sprouts from the ministrains of seminal origin, with approximately 3 years of development in a greenhouse. In the time between collecting the minicuttings and placing them in the substrate, the minicuttings were kept in a thermal box that contained water to prevent dehydration.

The minicuttings were then immersed for $10 \mathrm{~s}$ in a hydroethanolic solution $(50 \%$ ethanol and $50 \%$ distilled water by volume) containing IBA concentrations that vary according to the treatment. The minicuttings were placed in plastic cups of 300 $\mathrm{mL}$, filled with $250 \mathrm{~cm}^{3}$ of the commercial substrate mixture Mecplant ${ }^{\circledR}$ and vermiculite in a 1:1 ratio by volume. The minicuttings were placed in trays and kept in the greenhouse under controlled temperature $\left(25 \pm 3{ }^{\circ} \mathrm{C}\right)$ and humidity ( $\mathrm{RH}=80 \%$ ).

After 30 and 60 days, the minicuttings were evaluated for survival (\%) (green-colored minicuttings), root formation (\%) (primary adventitious roots originating from the minicut base), number of primary roots, average length of primary roots $(\mathrm{cm})$, presence of secondary roots (\%) (lateral adventitious roots of second order originating from the primary roots), callus formation at the base of the minicuttings (\%), and number of leaves.

After testing for normality of the errors using the Kolmogorov-Smirnov test and the homogeneity of variances using the Bartlett test, the averages were transformed where necessary by the function $\sqrt{x+0.5}$, where $\mathrm{x}$ is the observed value. Subsequently, they were analyzed using the analysis of variance (ANOVA) test followed by Tukey'spost hoc test with a $5 \%$ probability of error. The accuracy of the tests was measured using the variation index (IV) (PIMENTEL-GOMES, 2009). The software used was the Sisvar (System for Analysis of Variance) statistical package for Windows ${ }^{\circledR}$ version 5.1 (FERREIRA, 2014).

\section{RESULTS AND DISCUSSION}

All minicuttings survived in both cultivation periods. Thus, there was no mortality due to the high auxin concentrations, as has been reported for other species, such as for Sapium glandulatum, 
which showed an increase in minicutting mortality with an increase in the concentration of IBA or NAA (naphthaleneacetic acid) (FERREIRA et al., 2010).

There was a significant effect of IBA application $(\mathrm{P}=0.0002)$, cultivation period $(\mathrm{P}=0.0000)$, and the interaction between the two factors $(\mathrm{P}=0.0004)$ on root formation $(\mathrm{IV}=3.95)$. There was also a significant effect of IBA application $(\mathrm{P}=0.0013)$ and the interaction between the cultivation period and the IBA application $(\mathrm{P}=0.0126)$, but not of the cultivation period $(\mathrm{P}=0.9031)$ on the number of roots $(\mathrm{IV}=11.40)$.

The root formation at 30 days of cultivation in the absence of auxin was only $25 \%$, while with the use of $1000 \mathrm{mg} \mathrm{L}^{-1}$ and $4000 \mathrm{mg} \mathrm{L}^{-1}$ of IBA there was an increase to $91.7 \%$ (Table 1). At a concentration of $2000 \mathrm{mg} \mathrm{L}^{-1}$ of IBA, the average rhizogenesis differed significantly and was middle between these two values (Table 1).

Several factors are involved in the minicut rooting process, including the presence or absence of phytoregulators such as IBA that can increase the rooting speed and uniformity (HARTMANN et. al, 2002), which was observed in the present study. A rate of over $90 \%$ of rhizogenesisis particularly excellent, considering that they were obtained in just 30 days of cultivation. At 60 days of cultivation, minicuttings that presented a low rate of rhizogenesis at 30 days (treatments of $0 \mathrm{mg} \mathrm{L}^{-1}$ and $2000 \mathrm{mg} \mathrm{L}^{-1}$ of auxin) showed root growth, presenting between 90 and $100 \%$ root formation. These results allowed us to infer that, even at the lowest auxin concentration, after 30 days of cultivation, it is possible to obtain rooted minicuttings of this species for use, accelerating the production of seedlings in the nursery while simultaneously reducing production time and costs. In Ficus carica, when comparing the effect of the absence of auxin with that of the presence of $2000 \mathrm{mg} \mathrm{L}^{-1}$ of IBA, the largest root formation (70\%) occurred after 60 days of cultivation with auxin (OHLAND et al., 2009).

Regarding the number of roots, while the outcome for the $1000 \mathrm{mg} \mathrm{L}^{-1}$ treatment did not differ significantly from those of $2000 \mathrm{mg} \mathrm{L}^{-1}$ and $4000 \mathrm{mg}$ $\mathrm{L}^{-1}$ treatments, it stood out as despite the use of a lower concentration of auxin, and presented 8.42 roots per minicut after 30 days of cultivation (Table 1). Having a larger number of roots enhances the absorption of nutrients and accelerates the growth of clonal seedlings, and after 60 days, the effect of increasing this treatment was small and not significant $(8.42$ against 10.58), showing that 30 days of cultivation at $1000 \mathrm{mg} \mathrm{L}^{-1}$ of IBA is sufficient to produce seedlings with high quality and good economic return. On the contrary, in minicuttings of Handroanthus heptaphyllus, the largest number of roots formed after 30 days of cultivation with the application of a much higher concentration $\left(8000 \mathrm{mg} \mathrm{L}^{-1}\right)$ of IBA was 5.7 , a value lower than the value observed in the present research (OLIVEIRA et al., 2016).

For root length $(\mathrm{IV}=9.24)$ and secondary root $(\mathrm{IV}=5.36)$, there was a significant effect of IBA application $(\mathrm{P}=0.0068 ; \mathrm{P}=0.0153$, respectively $)$ and cultivation period $(\mathrm{P}=0.0000 ; \mathrm{P}=0.0000$, respectively), but not of the interaction between them ( $\mathrm{P}=0.1459 ; \mathrm{P}=0.5219$, respectively). However, for callus formation $(\mathrm{IV}=4.61)$, there was a significant effect only of the IBA treatment $(\mathrm{P}=0.0001)$; neither the cultivation period $(\mathrm{P}=0.3834)$ nor the interaction between the main factors $(\mathrm{P}=0.3991)$ were significant.

All treatments resulted in minicuttings with satisfactory root length, as shown in figure 1 .

Table 1 - Root formation (\%) and number of roots in Luehea divaricata Mart. \& Zucc. minicuttings as a function of the interaction between concentrations of Indolbutiric acid - IBA (0, 1000, 2000 or $\left.4000 \mathrm{mg} \mathrm{L}^{-1}\right)$ of hydroethanolic solutions $(50 \%$ ethanol, $50 \%$ distilled water, v/v) where they were previously immersed for $10 \mathrm{~s}$, and the cultivation period (30 or 60 days). Santa Maria, RS, UFSM, 2017.

\begin{tabular}{|c|c|c|c|c|}
\hline \multirow[t]{2}{*}{$\operatorname{IBA}\left(\mathrm{mg} \mathrm{L}^{-1}\right)$} & \multicolumn{2}{|c|}{ 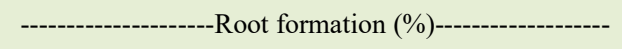 } & \multicolumn{2}{|c|}{-----------------------Number of roots---------------------- } \\
\hline & 30 days & 60 days & 30 days & 60 days \\
\hline 0 & $25.00 \mathrm{~B} \mathrm{c}^{*}$ & $100.00 \mathrm{~A} \mathrm{a}$ & $2.33 \mathrm{~A} \mathrm{~b}$ & $6.10 \mathrm{~A} \mathrm{a}$ \\
\hline 1000 & $91.70 \mathrm{~A} \mathrm{a}$ & $100.00 \mathrm{~A} \mathrm{a}$ & $8.42 \mathrm{~A} \mathrm{a}$ & $10.58 \mathrm{~A} \mathrm{a}$ \\
\hline 2000 & $58.34 \mathrm{~B} \mathrm{~b}$ & $91.70 \mathrm{~A} \mathrm{a}$ & $6.34 \mathrm{~A} \mathrm{a}$ & $6.34 \mathrm{~A} \mathrm{a}$ \\
\hline 4000 & $91.70 \mathrm{~A} \mathrm{a}$ & $100.00 \mathrm{~A} \mathrm{a}$ & $6.16 \mathrm{~B} \mathrm{a}$ & $11.58 \mathrm{~A} \mathrm{a}$ \\
\hline AVERAGE & 66.68 & 97.92 & 5.81 & 8.65 \\
\hline $\mathrm{IV}^{* *}$ & 3.95 & & 11.40 & \\
\hline
\end{tabular}

*Averages followed by the same lowercase letter in the columns, and uppercase in lines, do not differ significantly by the Tukey test at the $5 \%$ error probability level. ${ }^{* *}$ Index of variation (IV), calculated by $\mathrm{CV} / \sqrt{\mathrm{N}}$, where IV is equal to coefficient of variation (CV) divided by the square root of the number of repetitions (N). Source: Authors (2017). 


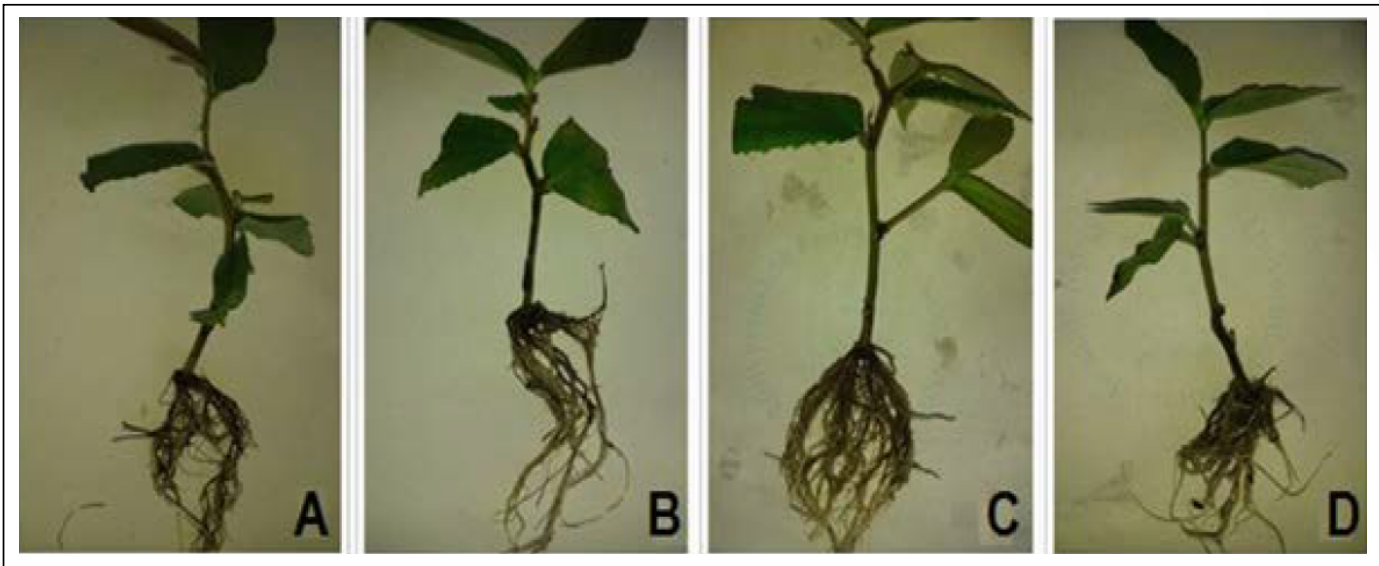

Figure 1 - Illustrative representation of the minicuttings of Luehea divaricata Mart. \& Zucc. which were subjected to "pulse" treatment for $10 \mathrm{~s}$ in hydroethanolic solution $(50 \%$ ethanol, $50 \%$ distilled water, v/v) of indolebutyric acid - IBA (0; 1000; 2000 or $\left.4000 \mathrm{mg} \mathrm{L}^{-1}\right)$, after 60 days. A) $0 \mathrm{mg} \mathrm{L}^{-1}$; B) $1000 \mathrm{mg} \mathrm{L}^{-1}$; C) $2000 \mathrm{mg} \mathrm{L}^{-1}$ and D) $4000 \mathrm{mg} \mathrm{L}^{-1}$.

Source: Authors (2017).

However, the greatest average lengths $(11.66 \mathrm{~cm}$ and $11.12 \mathrm{~cm}$ ) were obtained from the "pulse" treatment with $1000 \mathrm{mg} \mathrm{L}^{-1}$ and $4000 \mathrm{mg} \mathrm{L}^{-1}$, which did not differ from each other, but from the other treatments (Table 2). Thus, as previously mentioned, the concentration of $4000 \mathrm{mg} \mathrm{L}^{-1}$ produced significantly improved results for the number and length of the roots; however, since the lower concentration (1000 $\mathrm{mg} \mathrm{L}^{-1}$ ) did not yield significantly different results from those with the highest concentration, it is more economically viable to apply a smaller amount of phytoregulator to the base of the minicuttings of Luehea divaricata. A similar result to the one obtained in the present study was observed with Melaleuca alternifolia, which presented an average root length of $10.47 \mathrm{~cm}$ with the use of a higher concentration of IBA at $2000 \mathrm{mg} \mathrm{L}^{-1}$ (OLIVEIRA et al., 2012). In the minicuttings of Handroanthus heptaphyllus, a shorter average root length than that observed in this study was obtained $(4.47 \mathrm{~cm})$ by applying a much higher concentration (8000 $\mathrm{mg} \mathrm{L}^{-1}$ ) of IBA (OLIVEIRA, et al., 2016).

For the secondary root (Table 2), the concentration of $4000 \mathrm{mg} \mathrm{L}^{-1}$ stood out once more,

Table 2 - Average root length (cm), presence of secondary roots (\%) and presence of callus (\%) in minicuttings of Luehea divaricata Mart. \& Zucc. as a function of concentrations of Indolbutiric acid - IBA $\left(0,1000,2000\right.$ or $\left.4000 \mathrm{mg} \mathrm{L}^{-1}\right)$ of hydroethanolic solutions ( $50 \%$ ethanol, $50 \%$ distilled water, $\mathrm{v} / \mathrm{v}$ ) in which they were previously immersed for $10 \mathrm{~s}$ regardless of the cultivation period (30 or 60 days). Santa Maria, RS, UFSM, 2017.

\begin{tabular}{lccc}
\hline IBA $\left(\mathrm{mg} \mathrm{L}^{-1}\right)$ & Root length $(\mathrm{cm})$ & Secondary roots $(\%)$ & Callus $(\%)$ \\
\hline 0 & $7.71 \mathrm{~b}^{*}$ & $37.50 \mathrm{~b}$ & $95.83 \mathrm{a}$ \\
\hline 1000 & $11.66 \mathrm{a}$ & $62.50 \mathrm{ab}$ & $95.83 \mathrm{a}$ \\
2000 & $7.96 \mathrm{~b}$ & $45.83 \mathrm{ab}$ & $54.10 \mathrm{~b}$ \\
4000 & $11.12 \mathrm{a}$ & $66.67 \mathrm{a}$ & $83.34 \mathrm{a}$ \\
AVERAGE & 9.61 & 53.12 & 82.27 \\
IV $^{* *}$ & 9.24 & 5.36 & 4.61 \\
\hline
\end{tabular}

*Averages followed by the same letter in the columns do not differ significantly by the Tukey test at the $5 \%$ error probability level. * Index of variation (IV), calculated by $\mathrm{CV} / \sqrt{\mathrm{N}}$, where IV is equal to coefficient of variation (CV) divided by the square root of the number of repetitions (N). Source: Authors (2017).

Ciência Rural, v.49, n.12, 2019. 
as observed previously in the root formation (Table 1), but it did not differ from the averages obtained with 1000 and $2000 \mathrm{mg} \mathrm{L}^{-1}$, and those did not differ from the ones with the absence of auxin. However, considering the outcome of the treatments discussed so far, the use of $1000 \mathrm{mg} \mathrm{L}^{-1}$ still presents as the most efficient and effective treatment.

Callus formation (Table 2) increased with the use of most concentrations of IBA, and also in the absence of auxin. Potentially, callus formation occurred with the presence of the phytoregulator owing to a hormonal balance that was established in the tissue, with the endogenous levels of the hormones in contact with the exogenous auxin application. In the absence of IBA, the callus formation may have occurred due to the mechanical injury at the base of the minicut. The mechanical injury caused by the minicut collection does not affect mortality or rooting, but may induce callus formation (LIMA et al., 2013). Calluses are unorganized and irregularly differentiated cell masses; so, their presence at the base of the minicuttings can negatively affect the rooting (SCHMILDT et al., 2010). However, the observed callogenesis did not compromise the development of primary and secondary roots in minicuttings of Luehea divaricata. In Sapium glandulatum, for example, the callus formation was considered to impair the induction of adventitious roots. The authors reports that the rooting of the minicuttings was high because of the low callus formation rates (below 5\%), independent of the season in which the minicuttings were collected and the application of up to $8000 \mathrm{mg} \mathrm{L}^{-1}$ of IBA (FERREIRA et al., 2010).

The cultivation period of 60 days in a greenhouse is necessary for proper root and leaf development (Table 3). However, as noted earlier, minicuttings treated with $1000 \mathrm{mg} \mathrm{L}^{-1}$ of IBA at 30 days of cultivation already had higher root formation and number of roots than did treatments involving no auxin (Table 1). Cultivation for an additional 30 days led to higher root length, higher percentage of secondary roots and number of leaves (Table 3; Figure 1). For the number of leaves ( $\mathrm{IV}=12.17$ ), whose results have not yet been presented in this paper, it was observed that there was an effect only from the cultivation period ( $\mathrm{P}=0.0000)$, and not from IBA application $(\mathrm{P}=0.1156)$, nor from the interaction between these two factors $(\mathrm{P}=0.2102)$.

\section{CONCLUSION}

Application of $1000 \mathrm{mg} \mathrm{\textrm {L } ^ { - 1 }}$ of IBA in "pulse" treatment and a cultivation period of 30 days may promote rapid propagation of Luehea divaricata and has already yielded satisfactory results regarding root formation and number of roots produced. However, in order to obtain higher averages of secondary root formation, root length, and number of leaves, it is necessary to prolong the cultivation to a period of 60 days.

Table 3 - Averages of root length (cm), presence of secondary roots (\%) and number of leaves in minicuttings of Luehea divaricata Mart. \& Zucc. depending on the cultivation period (30 or 60 days), regardless of the concentration of the hydroethanolic solution $(50 \%$ ethanol, $50 \%$ distilled water, v/v) of Indolbutiric acid - IBA $\left(0,1000,2000\right.$ or $\left.4000 \mathrm{mg} \mathrm{L}^{-1}\right)$, in which they were previously immersed for 10s. Santa Maria, RS, UFSM, 2017.

\begin{tabular}{lccc}
\hline Period (days) & Root length $(\mathrm{cm})$ & Secondary roots (\%) & Number of leaves \\
\hline 30 & $4.40 \mathrm{~b}$ & $18.75 \mathrm{~b}$ & $0.21 \mathrm{~b}$ \\
60 & $14.80 \mathrm{a}$ & $87.50 \mathrm{a}$ & $3.50 \mathrm{a}$ \\
AVERAGE & 9.6 & 53.1 & 1.8 \\
IV & 9.24 & 5.36 & 12.17 \\
\hline
\end{tabular}

${ }^{*}$ Averages followed by the same letter in the columns do not differ significantly by the $\mathrm{F}$ test at the $5 \%$ error probability level. ${ }^{* *}$ Index of variation (IV), calculated by $\mathrm{CV} / \sqrt{\mathrm{N}} \mathrm{CV} / \sqrt{\mathrm{N}}$, where IV is equal to coefficient of variation (CV) divided by the square root of the number of repetitions (N). Source: Authors (2017). 


\section{ACKNOWLEDGEMENTS}

This study was funded by the Brazilian National Research Council (CNPq - 312499/2018-3) and the Brazilian Federal Agency for Support and Evaluation of Graduate Education (CAPES - 88882.427782/2019-01).

\section{DECLARATION OF CONFLICT OF INTERESTS}

The authors declare that they have no conflict of interest. The founding sponsors had no role in the design of the study, nor in the data collection, analyses, or interpretation of data, the writing of the manuscript, nor the decision to publish the results.

\section{AUTHORS' CONTRIBUTIONS}

All authors contributed equally for the conception and writing of the manuscript. All authors critically revised the manuscript and approved of the final version.

\section{REFERENCES}

ASSIS, T. F.; TEIXEIRA, S. L. Enraizamento de plantas lenhosas. In: TORRES, A.C.; CALDAS, L. S.; BUSO, J. A. Cultura de Tecidos e Transformação Genética de Plantas. v. 1. Brasília: Embrapa-SPI/Embrapa - SNPH, 1998. p. 262-297.

BRASIL. Ministério do Meio Ambiente. Mapa de Vegetação Nativa na Área de Aplicação da Lei no. 11.428/2006 - Lei da Mata Atlântica (ano base 2009). FUNCATE. Brasília, DF. 2015. 84 p.

CAMPANILI, M.; SCHAFFER, W. B. Mata Atlântica: manual de adequação ambiental. Brasília: MMA/SBF, 2010. 96 p.

DUTRA, A. F.; ARAUJO, M. M.; RORATO, D.; MIETH, P. Germinação de sementes e emergência de plântulas de Luehea divaricata Mart. et. Zucc. em diferentes substratos. Ciência Florestal, Santa Maria, v.26, n.2, p.411-418, 2016. Available from: <http://www.scielo.br/pdf/cflo/v26n2/01039954-cflo-26-02-00411.pdf $>$. Accessed: Dec. 22, 2018. doi: $10.5902 / 1980509822744$.

FERREIRA, D. F. Sisvar: a Guide for its Bootstrap procedures in multiple comparisons. Ciência e agrotecnologia, v. 38, n 2, p 109-112, 2014. Available from: <http://www.scielo.br/pdf/cagro/v38n2/ a01v38n2.pdf>. Accessed: Aug. 22, 2017. doi: 10.1590/S141370542014000200001
FERREIRA, M. E. et al. Miniestaquia de Sapium glandulatum (vell.) pax com o uso de Ácido Indol Butirico e Ácido Naftaleno Acético. Ciência Florestal, v.20, n.1, p.19-31, 2010. Available from: $<\mathrm{https}: / /$ periodicos.ufsm.br/cienciaflorestal/article/view/1758>. Accessed: Aug. 22, 2017. doi: 10.5902/198050981758.

HARTMANN, H. T.; KESTER, D. E.; DAVIES JUNIOR, F. T.; GENEVE, R. L. Plant Propagation: principles and practices. 7. ed. New Jersey: Prentice Hall, 2002. 880 p.

LIMA J. D.; BOLFARINI A. C. B.; MODENESE-GORLA DA SILVA S. H.; MORAES W. S. Propagação de Camellia sinensis: efeito do genótipo, estaca, substrato, recipiente e ácido indolbutírico. Horticultura Brasileira, v.31, p.74-79, 2013. Available from: $<$ http://www.scielo.br/pdf/hb/v31n1/v31n1a12.pdf $>$. Accessed: Dec. 12, 2018. doi: 10.1590/S0102-05362013000100012.

LORENZI, H. Árvores brasileiras: manual de identificação e cultivo de plantas arbóreas nativas do Brasil, vol 1 . Nova Odessa: Plantarum. 2008. 384p.

OHLAND, T. et al. Enraizamento de estacas apicais de figueira 'Roxo de Valinhos' em função de época de coleta e AIB. Ciência e Agrotecnologia, v.33, n.1, p.74-78, 2009. Available from: $\quad<$ http://www.scielo.br/scielo.php?script=sci arttext\&pid $=$ S1413-70542009000100010 $>$. Accessed: Sep. 02, 2017. doi: 10.1590/S1413-70542009000100010.

OLIVEIRA, Y. et al. Substratos, concentrações de ácido indolbutírico e tipos de miniestacas no enraizamento de melaleuca (Melaleuca alternifolia Cheel). Revista Brasileira de Plantas Medicinais, v. 14, n. 4, p. 611-616, 2012. Available from: < http:// www.scielo.br/pdf/rbpm/v14n4/06.pdf>. Accessed: Sep. 05, 2017. doi: 10.1590/S1516-05722012000400006.

OLIVEIRA, T. P. F.; et al. Aplicação de AIB e tipo de miniestacas na produção de mudas de Handroanthus heptaphyllus Mattos. Ciência Florestal, v.26, n.1, p.313-320, 2016. Available from: <http:// www.scielo.br/pdf/cflo/v26n1/0103-9954-cflo-26-01-00313.pdf $>$. Accessed: Sep. 05, 2017. doi: 10.5902/1980509821128

PIMENTEL-GOMES, F. Curso de estatística experimental. 15 ed., Piracicaba: FEALQ, 2009, 451p.

SCHMILDT, E. R. et al. Níveis de ácido indolbutírico (AIB) no enraizamento in vitro de microestacas de mamoeiro 'Tainung 01'. Acta ScientiarumAgronomy. Maringá, v.32, n.1, p.125-129, 2010. Available from: <http://www.scielo.br/pdf/asagr/v32n1/v32n1a18> Accessed: Sep. 09, 2018. doi: 10.4025/actasciagron.v32i1.866.

XAVIER, A. et al. Propagação vegetativa de cedro-rosa por miniestaquia. Revista Árvore, v.27, n.2, p.139-143, 2003. Available from: <http://www.scielo.br/pdf/rarv/v27n2/15932.pdf>. Accessed: Sep. 20, 2017. doi: 10.1590/S0100-67622003000200003. 